\title{
Correlations of EGFR mutations and increases in EGFR and HER2 copy number to gefitinib response in a retrospective analysis of lung
} cancer patients

\author{
Trevor J Pugh ${ }^{\dagger 1}$, Gwyn Bebb ${ }^{\dagger 2}$, Lorena Barclay3, Margaret Sutcliffe ${ }^{3}$, \\ John Fee ${ }^{3}$, Chris Salski ${ }^{4}$, Robert O'Connor ${ }^{4}$, Cheryl Ho ${ }^{5}$, Nevin Murray ${ }^{5}$, \\ Barbara Melosky5, John English ${ }^{6}$, Jeurgen Vielkind ${ }^{3}$, Doug Horsman ${ }^{4}$, \\ Janessa J Laskin ${ }^{5}$ and Marco A Marra*1
}

\begin{abstract}
Address: ${ }^{1}$ Michael Smith Genome Sciences Centre, BC Cancer Agency, Vancouver, Canada, ${ }^{2}$ Tom Baker Cancer Centre, Calgary, BC, Canada, ${ }^{3}$ Department of Cancer Endocrinology, BC Cancer Agency, Vancouver, Canada, ${ }^{4}$ Department of Pathology, BC Cancer Agency, Vancouver, Canada, ${ }^{5}$ Department of Medical Oncology, BC Cancer Agency, Vancouver, Canada and ${ }^{6}$ Department of Pathology and Laboratory Medicine, Vancouver Hospital, Vancouver, Canada

Email: Trevor J Pugh - tpugh@bcgsc.ca; Gwyn Bebb - gwynbebb@cancerboard.ab.ca; Lorena Barclay - lbarclay@bccrc.ca; Margaret Sutcliffe - msutclif@bccrc.ca; John Fee - jfee@bccancer.bc.ca; Chris Salski - csalski@bccancer.bc.ca;

Robert O'Connor - robert.oconnor@vch.ca; Cheryl Ho - cho@bccancer.bc.ca; Nevin Murray - nmurray@bccancer.bc.ca; Barbara Melosky - bmelosky@bccancer.bc.ca; John English - john.english@vch.ca; Jeurgen Vielkind - jvielkin@bccancer.bc.ca; Doug Horsman - dhorsman@bccancer.bc.ca; Janessa J Laskin - jlaskin@bccancer.bc.ca; Marco A Marra* - mmarra@bcgsc.ca

* Corresponding author †Equal contributors
\end{abstract}

Published: 13 July 2007

BMC Cancer 2007, 7:128 doi:10.1186/147/-2407-7-128

This article is available from: http://www.biomedcentral.com//47/-2407/7//28

(C) 2007 Pugh et al; licensee BioMed Central Ltd.

This is an Open Access article distributed under the terms of the Creative Commons Attribution License (http://creativecommons.org/licenses/by/2.0), which permits unrestricted use, distribution, and reproduction in any medium, provided the original work is properly cited.
Received: 29 March 2007

Accepted: I July 2007

\begin{abstract}
Background: Gefitinib, a small molecule tyrosine kinase inhibitor of the Epidermal Growth Factor Receptor (EGFR), has shown limited efficacy in the treatment of lung cancer. Recognized clinical predictors of response to this drug, specifically female, non-smoker, Asian descent, and adenocarcinoma, together suggest a genetic basis for drug response. Recent studies have addressed the relationship between response and either sequence mutations or increased copy number of specific receptor tyrosine kinases. We set out to examine the relationship between response and the molecular status of two such kinases, EGFR and HER2, in 39 patients treated with gefitinib at the BC Cancer Agency.
\end{abstract}

Methods: Archival patient material was reviewed by a pathologist and malignant cells were selectively isolated by laser microdissection or manual recovery of cells from microscope slides. Genomic DNA was extracted from 37 such patient samples and exons 18-24, coding for the tyrosine kinase domain of EGFR, were amplified by PCR and sequenced. EGFR and HER2 copy number status were also assessed using FISH in 26 samples. Correlations between molecular features and drug response were assessed using the two-sided Fisher's exact test.

Results: Mutations previously correlated with response were detected in five tumours, four with exon 19 deletions and one with an exon 21 missense L858R point mutation. Increased gene copy number was observed in thirteen tumours, seven with EGFR amplification, three with HER2 amplification, and three with amplification of both genes. In our study cohort, a correlation was not observed between response and EGFR mutations (exon 19 deletion $p=0.0889$, we observed a single exon $2 \mathrm{I}$ mutation in a non-responder) or increases in EGFR or HER2 copy number $(\mathrm{p}=0.552$ and 0.437 , respectively).

Conclusion: Neither mutation of EGFR nor increased copy number of EGFR or HER2 was diagnostic of response to gefitinib in this cohort. However, validation of these features in a larger sample set is appropriate. Identification of additional predictive biomarkers beyond EGFR status may be necessary to accurately predict treatment outcome. 


\section{Background}

Lung cancer is the leading cause of cancer-related death in North America with $85 \%$ of patients eventually succumbing to the disease [1]. The five year survival rate for this cancer is low (16\%) compared to other cancers [1] and there exists a major need for additional therapeutic strategies in its treatment. EGFR has been identified as a potential therapeutic target as overexpression is observed in 40$80 \%$ late stage lung tumours and can confer a malignant phenotype in cultured cells [2]. The FDA has approved the use of two EGFR-targeted molecules, gefitinib ("Iressa" from Astra Zeneca) and erlotinib ("Tarceva" from Genentech/Roche) in the second- and third-line treatment of lung cancer. Both of these drugs were designed to reversibly bind the ATP-binding pocket of the EGFR tyrosinekinase domain, thereby inhibiting autophosphorylation and stimulation of downstream signalling pathways resulting in inhibition of proliferation, delayed cell cycle progression, and increased apoptosis. In international phase II trials, $\sim 28 \%$ of Japanese patients responded to gefitinib versus $\sim 10 \%$ of patients of European descent as assessed by symptom improvement and tumour shrinkage $[3,4]$. These population-specific findings have suggested that response to these drugs has a genetic component although regional environmental factors have not been discounted.

Somatic mutations in the EGFR tyrosine-kinase domain have been correlated with reduced tumour size as a result of treatment with gefitinib [5-9]. These mutations were commonly found in patients fitting the responsive profile observed in initial and subsequent clinical studies $[3,4,10]$, specifically female non-smokers of Asian descent. In a review of sixteen studies, EGFR mutations clustering around the tyrosine kinase domain ATP-binding pocket have been observed in 151 of 191 gefitinib responders $(79.1 \%)$ and 11 of 19 erlotinib responders (57.9\%) [11]. Confounding the model of mutation-mediated drug response is the finding that 40 of 191 gefitinib responders $(20.9 \%)$ and 8 of 19 erlotinib responders (42.1\%) lack EGFR mutations [11]. Conversely, EGFR mutations were seen in 40 of 355 gefitinib non-responders $(11.3 \%)$ and 16 of 117 erlotinib non-responders $(13.7 \%)$ [11] suggesting that somatic EGFR mutations are neither necessary nor sufficient for response. This suggestion is supported by the findings of a prospective trial of gefitinib in which 4 of 16 patients selected for tumours with EGFR mutations didn't respond to gefitinib [12]. An increasing number of studies examining the tumours of patients treated with gefitinib and erlotinib have correlated increased EGFR gene copy number with response $[9,13,14]$. Data analysis from a recent phase III trial of erlotinib has supported these observations [15]. In this trial, the response rate among patients with tumours with amplification of EGFR was significantly higher than those without this characteristic (20\% vs. $2 \%$ ) [15]. Multivariate analysis revealed that only EGFR expression and increased copy number were associated with erlotinib response and no correlation between base-pair mutation and response was found [15]. Increased HER2/Neu gene copy number has also been associated with response, particularly in the presence of increased EGFR copy number, EGFR overexpression or EGFR mutation [14]. Other studies have shown that tumours co-expressing HER2 and EGFR have a poor prognosis $[16,17]$ suggesting that there is a relationship between these genes that drives pathogenesis and which may be targeted by gefitinib. Additional data are needed to explore the ability of these molecular features to predict response to EGFR-targeted tyrosine-kinase inhibitors $[18,19]$.

Recently we confirmed that Asian ethnicity still predicts for response to gefitinib in a Canadian setting. We retrospectively analysed the experience of the Vancouver Cancer Centre in using gefitinib in a population in which $38 \%$ of patients are of Asian descent [10]. To test previous correlations of molecular features with response, we retrospectively analyzed diagnostic samples from this cohort of patients for somatic EGFR mutations as well as copy number alterations in HER2 and EGFR.

\section{Methods \\ Patient population \& assessment response}

Samples for molecular analysis were drawn from patients who received gefitinib through the Extended Access Program at the BC Cancer Agency as reported by Ho et al [10] with ethics approval from the BC Cancer Agency Ethics Review Board. The criteria for enrolment in the program were the presence of histologically or cytologically confirmed locally advanced or metastatic NSCLC having received prior standard systemic or radiation therapy or being ineligible for standard treatment. Patients received gefitinib following standard systemic or radiation therapy and response was assessed radiographically according to the SWOG modification of the WHO criteria [20]. In brief, complete response (CR) was defined as a complete disappearance of disease, partial response (PR) was defined as a decrease of $>50 \%$ of the sum of the products of the maximal perpendicular dimensions of measurable lesions, stable disease (SD) was defined as the presence of no new lesions or progression of current lesions, progressive disease (PD) was defined as an increase of $>50 \%$ of the sum of the products of the maximal perpendicular dimensions of measurable lesions, the development of new lesions, recurrence of lesions that had previously disappeared or failure to return for evaluation because of symptomatic deterioration. 


\section{Laser microdissection and DNA extraction}

To identify tumour cell populations for laser microdissection (LM) or manual scrape, malignant cells (cytology specimens) or tissues (paraffin embedded biopsies) were reviewed by a single reference pathologist. Because the DNA extracted from formalin-fixed, paraffin-embedded tissue blocks is of variable quality, the DNA from these sources was characterized prior to microdissection. DNA was extracted from a full 8 micron section of each block using the "Laser-Microdissected Tissues" protocol of the QIAamp spin-column kit (QIAgen, Valencia, CA). The digestion volumes were increased five-fold and three final $30 \mathrm{uL}$ elutions of TE (10:0.1) were performed. The DNA was quantified by PicoGreen assay (Invitrogen, Carlsbad, CA) and observed on a $2 \%$ agarose gel stained with ethidium bromide. For a block to qualify for LM, the presence of DNA fragments > 2000 bp was required (Figure 1). 40 archival samples from 37 patients were suitable for LM

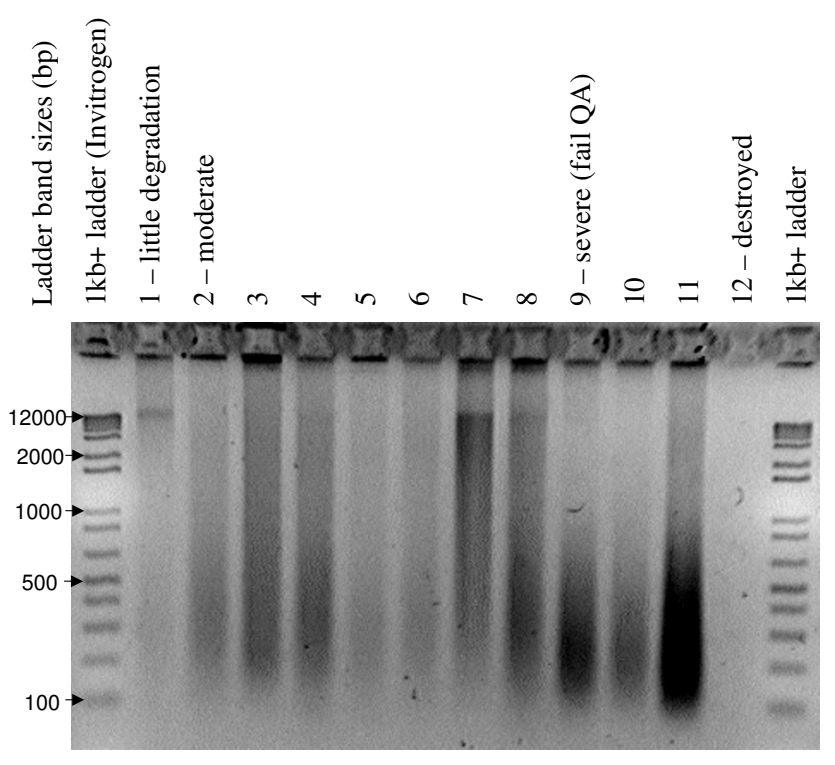

\section{Figure I}

DNA of varying quality from formalin-fixed paraffinembedded tissues. DNA extracted from tissue blocks is often degraded and chemically modified to varying degrees due to differences in fixation method and time, storage conditions, and nature of the tissue. Diagnostic treatments such as fixation with Bouin's (samples 9-I I) or acid decalcification (sample 12) can result in severely degraded template unusable for PCR. Little (sample I) or moderately (sample 2-8) degraded templates can be used for PCR although additional input DNA may be necessary for robust PCR. To ensure that blocks with degraded DNA were not used in labour-intensive microdissection, DNA from whole sections was extracted and qualified on a $2 \%$ agarose gel prior to microdissection of additional sections. Blocks yielding highly degraded DNA were not used in this study. and yielded enough DNA of sufficient quality for PCR and sequencing.

Laser microdissection of pathologist-identified cells was performed on serial sections of paraffin blocks using either the Arcturus PixCell infra-red laser-capture or MMI SL $\mu$ CUT UV laser microdissection instruments. Dissected cells were isolated onto the adhesive caps of $1.0 \mathrm{~mL}$ microcentrifuge tubes (Arcturus) (Figure 2). Material from cytology slides was scraped with a razor blade directly into microcentrifuge tubes and DNA extracted as described above.

\section{PCR and sequencing of EGFR exons I 8-24}

Exons 18-24, coding for the tyrosine kinase domain of EGFR, were amplified by PCR and sequenced. PCR primers were designed using human genome reference sequence acquired from the UCSC Genome Browser [21,22] (hg17_refGene_NM_005228). Primers were designed to anneal within introns at least 40 bp away from exon splice sites using the Primer3 program [23]. Sequencing tags were added to all PCR primers for downstream sequencing and experimentally optimized for annealing temperature. The DNA sequence and annealing temperatures $\left(\mathrm{T}_{\mathrm{ann}}\right)$ of all seven EGFR primer pairs are listed in Table 1. PCR reactions were performed in $20 \mathrm{uL}$ and consisted of: $2.0 \mathrm{uL} \mathrm{10 \times} \mathrm{Pfx} \mathrm{Amplification} \mathrm{Buffer}$

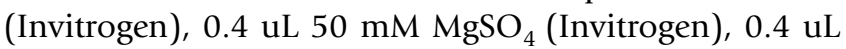
$10 \mathrm{mM}$ dNTPs (from $100 \mathrm{mM}$ stock, Invitrogen), $1 \mathrm{uL}$ each of $10 \mathrm{uM}$ forward and reverse primers (Invitrogen), $2.0 \mathrm{uL} 10 \times \mathrm{PCR}_{\mathrm{x}}$ Enchancer (Invitrogen), $0.1 \mathrm{uL} 2.5 \mathrm{U} / \mathrm{uL}$ Pfx Polymerase (Invitrogen) with 5-10 ng template and distilled water added up to the final volume. Reactions were cycled on an MJResearch Tetrad at $95 \mathrm{C}$ for 5 minutes followed by 35 cycles of $95 \mathrm{C}$ for $30 \mathrm{~s}_{\mathrm{ann}}$ for $15 \mathrm{~s}$ (Table 1 ), and $70 \mathrm{C}$ for 2 minutes. PCR products were purified using the Ampure magnetic-bead-based PCR product purification system (Agencourt, Beverly, MA).

Sequencing of PCR products was performed with standard chemistries in use by the production sequencing team at the BC Cancer Agency Michael Smith Genome Sciences Centre. Briefly, "forward" and "reverse" $1 / 24 \times$ reactions contained 0.33 uL BigDye Ready Reaction Mix v3.1 (ABI), 0.4 uL 15× Big Dye Buffer (50\% by volume Big Dye v3.1 Sequencing Buffer (ABI), 50\% by volume Tris-EDTA), $0.02 \mathrm{uL}$ distilled water, and $2 \mathrm{uL}$ of purified PCR product. Reactions were cycled 50 times with annealing temperatures $\left(\mathrm{T}_{\mathrm{ann}}\right)$ appropriate to the forward and reverse sequencing primers in use $\left(96^{\circ} \mathrm{C}\right.$ for $10 \mathrm{~s}, \mathrm{~T}_{\text {ann }}$ for $5 \mathrm{~s}, 60^{\circ} \mathrm{C}$ for 3 mins). All reactions were precipitated in a final concentration of $70 \%$ ethanol and $10 \mathrm{mM}$ EDTA and spun at $2750 \mathrm{~g}$ for 30 minutes to pellet sequencing products. The pellet was washed with $30 \mathrm{uL}$ of $70 \%$ ethanol and air dried before resuspension in $10 \mathrm{uL}$ distilled water. 

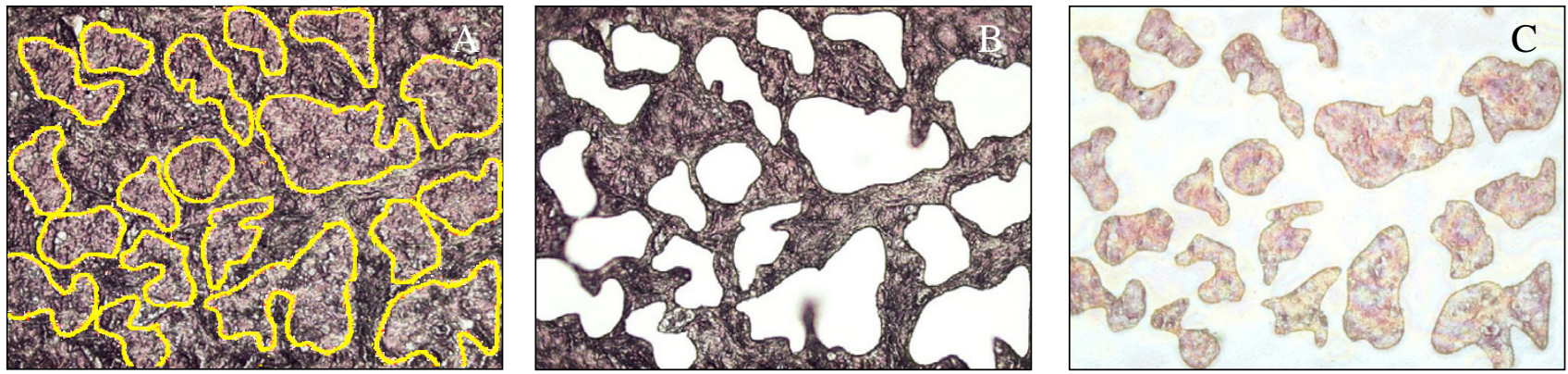

Figure 2

Laser microdissection of mixed tumour \& normal cell populations. Tumour cells were microdissected using an MMI SL $\mu$ CUT UV laser microdissection instrument to isolate tumour cells from surrounding normal tissue. A) Uncut lymph node tissue with metastatic tumour populations outlined in yellow. B) Normal stromal cells remaining after excision of tumour. C) Tumor cells isolated on adhesive cap.

Sequencing reaction products were analyzed on automated ABI 3730XL sequencers and traces analyzed using the Mutation Surveyor software package (SoftGenetics, State College, PA) and the Phred/Phrap/Consed suite $[24,25]$. All sequences were compared against human genome sequence (NCBI accession NM_005228.3) to identify mutations and polymorphisms. Observed known polymorphisms recorded in the Single Nucleotide Polymorphism database (dbSNP) $[26,27]$ were identified by appropriate 'rs' number. To further validate results, PCR and sequencing reactions were repeated for all samples in which an apparent mutation was observed. Correlations between clinical features and EGFR mutations were assessed using the two-sided Fisher's exact test.

\section{Copy number analysis of EGFR and HER2}

To assess EGFR and HER2 copy number, fluorescent insitu hybridization (FISH) was conducted using Pathvysion EGFR and HER-2 DNA Probe kits (Vysis, Downers Grove, IL). Formalin-fixed paraffin-embedded tissues were prepared in serial 6 um sections on positively charged Colorfrost/Plus microscope slides (Fisher Scientific, Hampton,
$\mathrm{NH}$ ). One section was H\&E stained and tumour populations identified by a pathologist. Hybridization areas were marked with a diamond-tipped pencil on the back of each slide. Sections were incubated overnight at $56^{\circ} \mathrm{C}$, dewaxed by exposure to xylene for 10 minutes, dehydrated in $100 \%$ ethanol for 5 minutes, and air-dried $2-4$ minutes on a slide warmer set to $37-45^{\circ} \mathrm{C}$. The slides were immersed in $0.2 \mathrm{~N} \mathrm{HCl}$ for 20 minutes, rinsed in $\mathrm{H}_{2} \mathrm{O}$ for 10 minutes, and incubated in $1 \mathrm{M} \mathrm{NaSCN}$ pretreatment solution (Vysis) for 30 minutes at $80^{\circ} \mathrm{C}$. After rinsing with room temperature $\mathrm{H}_{2} \mathrm{O}$ for 3 minutes, sections were digested with pepsin $(0.25 \mathrm{mg} / \mathrm{mL}$ in $0.01 \mathrm{~N}$ $\mathrm{HCl}$ ) for $15-18$ minutes at $37^{\circ} \mathrm{C}$, and rinsed with room temperature $\mathrm{H}_{2} \mathrm{O}$ for 5 minutes. Tissue morphology was assessed by phase contrast microscopy to ensure sufficient digestion of the collagen matrix. Slides were dehydrated with two 4-minute treatments of $100 \%$ ethanol and airdried 2-4 minutes on a slide warmer set to $37-45^{\circ} \mathrm{C}$. 2.5$3 \mathrm{uL}$ of the EGFR/CEP7 or HER2/CEP17 probe mixture was applied to the hybridization area marked on the slide and covered with a glass coverslip. Edges were sealed with rubber cement. The slides were incubated at $73^{\circ} \mathrm{C}$ for 5

Table I: PCR primers for 7 exons of the EGFR tyrosine kinase domain

\begin{tabular}{ccllc}
\hline Exon & $\begin{array}{c}\text { Annealing Tempera- } \\
\text { ture, }{ }^{\circ} \mathbf{C}\left(\mathbf{T}_{\text {ann }}\right)\end{array}$ & \multicolumn{1}{c}{$\begin{array}{c}\text { Forward Primer } \\
\text { Sequence }\end{array}$} & \multicolumn{1}{c}{$\begin{array}{c}\text { Reverse Primer } \\
\text { Sequence }\end{array}$} & $\begin{array}{c}\text { Product Length (with } \\
\text { seq tags) }\end{array}$ \\
\hline 18 & 60 & gtgtcctggcacccaagc & ccccaccagaccatgaga & 340 \\
19 & 60 & cagcatgtggcaccatctc & cagagcagctgccagacat & 273 \\
20 & 60 & cattcatgcgtcttcacttg & catatcccatggcaaactc & 412 \\
21 & 60 & agccataagtcctcgacgtg & acccagaatgtctggagagc & 372 \\
22 & 56 & tccagagtgagttaacttttcca & ttgcatgtcagaggatataatgtaa & 277 \\
23 & 60 & gaagcaaattgcccaagact & atttctccagggatgcaaag & 413 \\
24 & 56 & gcaatgccatctttatcatttc & gctggcatgtgacagaacac & 281 \\
\hline
\end{tabular}

PCR primers were designed at least $40 \mathrm{bp}$ from EGFR exons coding for the tyrosine kinase domain. Sequencing tags were added to each primer to allow sequencing of the PCR products. All forward primer sequences were prefixed with a -2IMI3 sequencing tag, TGTAAAACGACGGCCAGT. All reverse primer sequences were prefixed with an MI3R sequencing tag, CAGGAAACAGCTATGAC. -2 IMI 3 and MI3R sequencing primers were then used in the corresponding sequencing reaction to generate sequences from both strands of the PCR products. 
minutes then $37^{\circ} \mathrm{C}$ overnight to first co-denaturate the probe and chromosomal DNA and then allow hybridization. Rubber cemented coverslips were then removed and the slides were placed in a post-hybridization wash solution $(2 \times \mathrm{SSC}, 0.3 \% \mathrm{NP}-40)$ at $72^{\circ} \mathrm{C}$ for 2 minutes. After rinsing the slides in $1 \times \mathrm{PBS}$, they were air-dried in the dark for 30-60 minutes. $4 \mathrm{uL}$ DAPI-1 counterstain (Vysis) was applied to the hybridization area and coverslipped. FISH analysis was performed by counting the number of signals from each probe in forty tumour nuclei on each slide.

Two approaches were used to interpret raw FISH probe counts and define gene amplification. In the first approach, the total number of EGFR or HER2 signals was divided by the total number of centromeric CEP7 or CEP17 signals and a gene/CEP ratio reported for the population of forty cells. Samples with a gene/CEP ratio $\geq 2$ were defined as displaying gene amplification. The second approach applies published criteria [13] to raw FISH counts to classify patients into six strata according to the frequency of cells with specific gene copy numbers within the tumour population. The six strata, as published [13] and applied in our study, were: 1$)$ disomy ( $\leq 2$ copies in $>$ $90 \%$ of cells); 2 ) low trisomy ( $\leq 2$ copies in $\geq 40 \%$ of cells, 3 copies in $10 \%-40 \%$ of the cells, $\geq 4$ copies in $<10 \%$ of cells); 3 ) high trisomy ( $\leq 2$ copies in $\geq 40 \%$ of cells, 3 copies in $\geq 40 \%$ of cells, $\geq 4$ copies in $<10 \%$ of cells); 4 ) low polysomy ( $\geq 4$ copies in $10 \%-40 \%$ of cells); 5 ) high polysomy ( $\geq 4$ copies in $\geq 40 \%$ of cells); and 6 ) gene amplification (defined by presence of tight EGFR gene clusters and a ratio of EGFR gene to chromosome of $\geq 2$ or $\geq 15$ copies of EGFR per cell in $\geq 10 \%$ of analyzed cells). The first approach is commonly used in practical clinical assessment of gene copy number and generally reflects the average copy number of the cell population examined. The second approach attempts to capture the degree to which gene amplification defines a cell population. While the biological significance of the second method is unknown, it has been shown to predict response in the case of gefitinib and increased EGFR copy number [13].

\section{Results \\ Patient population}

We previously documented the clinical characteristics of a population of 61 patients treated with gefitinib at the BC Cancer Agency between April 2002 and May 2004 [10]. In the previous study of 61 patients, those with Asian ethnicity and adenocarcinoma histology displayed a preferential response to gefitinib. Diagnostic samples from 39 of these individuals were suitable for microdissection and yielded DNA of sufficient quality for PCR and sequencing and/or copy number analysis by FISH. Microdissected materials were used to avoid masking of cancer-specific features by contaminating normal material. Figure 2 demonstrates the heterogeneous nature of a metastatic tumour and the ability of laser microdissection to separate tumour cells from surrounding normal tissue. The patient subset consisted of 23 females (59\%), 17 patients of Asian descent (44\%), 12 non-smokers (31\%), 34 tumours of adenocarcinoma subtype (87\%), and a distribution between partial response/stable disease/progressive disease of $6 / 14 / 17$ (15\%/33\%/44\%) and 2 patients lacking a response assessment. The clinical characteristics and molecular status of these patients are described in Supplemental Table 1 (see Additional file 1).

\section{EGFR tyrosine-kinase domain mutations}

We studied the DNA sequence of the EGFR tyrosine kinase domain in our patient samples as this domain was previously associated with increased gefitinib sensitivity [5-7]. In eight of thirty-eight tumours assessed we found ten mutations, five of which have been previously correlated with response (Figure 3). Four of these mutations were inframe deletions or substitutions within exon 19, all of which impacted L747-A750 (Table 2) and retained the ATP-binding lysine moiety. Two of these patients were responsive to gefitinib, three were female, three were nonsmokers (the smoking status for the remaining patient was unknown) and all four were of Asian descent. We resequenced the normal tissue remaining after microdissection in two of these samples and found no mutations suggesting that these mutations were specific to tumour, consistent with previous reports. The fifth mutation was a homozygous missense point mutation within exon 21 resulting in an L858R substitution (Table 3). This patient was a female non-smoker of Asian descent that did not respond to gefitinib. Three missense and two synonymous point mutations were detected in exon 20, four of which have been previously observed (Table 3 ). One of these mutations was in a tumour from one of the drug responsive patients that also had an exon 19 deletion. The exon 20 T790M mutation previously documented to confer resistance to gefitinib [28] was not observed. The exon 20 point mutations we observed are unlikely to be artifactual as previously postulated [29], as similar mutations were not observed in any of the other amplicons we sequenced.

We were unable to validate the previously reported relationships between response and the presence of exon 19 mutations $(\mathrm{p}=0.0889)$ or exon 21 mutations (we observed a single mutation in a non-responder). If patients exhibiting stable disease were counted among the responders ("disease control"), correlation between exon 19 deletions and response was not observed ( $\mathrm{p}=1.00)$. The presence of exon 19 mutations was correlated with Asian ethnicity $(\mathrm{p}=0.0207)$ and non-smoking status $(\mathrm{p}=$ $0.0406)$ but not with female gender $(p=0.633)$ or adenocarcinoma histology $(\mathrm{p}=1.00)$. When taken as aroup, there were no correlations with response and exon 20 mutations ( $p=0.0889)$, female gender $(p=0.633)$, non- 


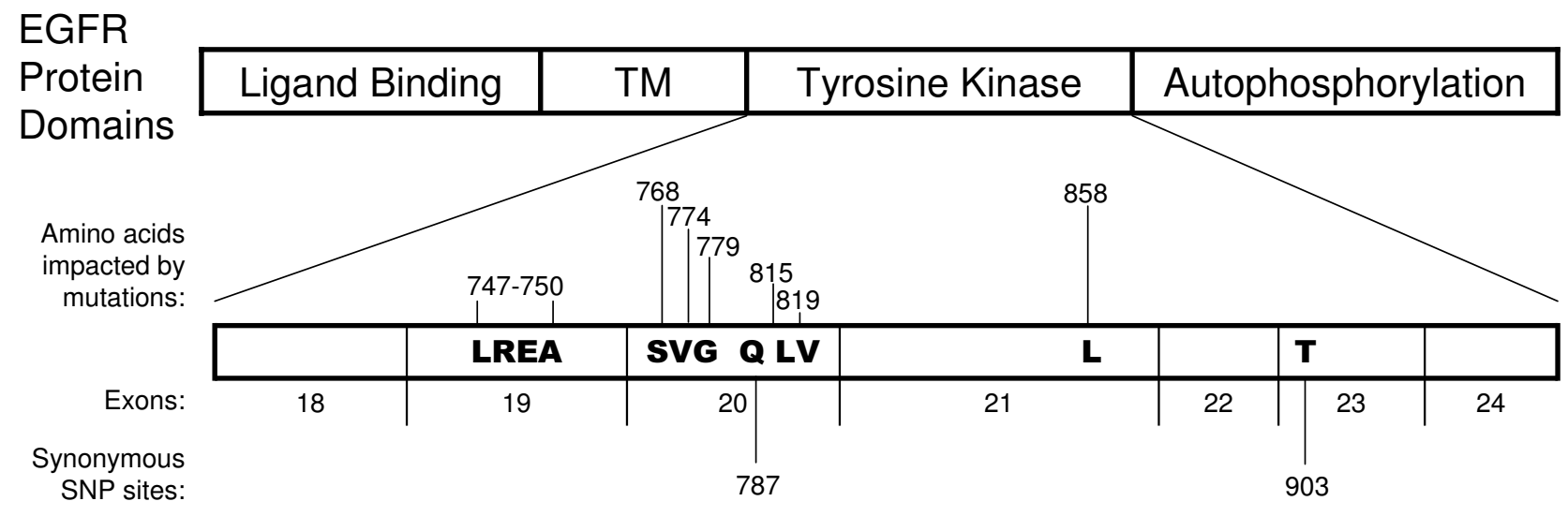

\section{Figure 3}

EGFR variant detection summary. The seven exons coding for the tyrosine kinase domain of EGFR were sequenced in 37 tumours. Eight of these samples contained mutations, four with in-frame exon 19 deletions impacting L747-A750, four with a variety of exon 20 point mutations, and one with an exon 21 point mutation, L858R. Two previously documented synonymous polymorphisms were detected in this study, G2607A in exon 20 (rs I 025I 977) and T2955C in exon 23 (rs 17290643). Amino acid numbering is from the initial methionine residue of the EGFR protein isoform a (NCBI accession NP_005219).

smoking status $(\mathrm{p}=1.00)$, Asian ethnicity $(\mathrm{p}=1.00)$, adenocarcinoma subtype $(\mathrm{p}=1.00)$, or disease control $(\mathrm{p}=$ $0.104)$.

\section{EGFR Tyrosine-kinase Domain Polymorphisms}

We detected two previously documented single nucleotide polymorphisms (dbSNP rs10251977, rs17290643). Exon 20 harbours the synonymous G/A SNP rs10251977 while exon 23 contains the synonymous SNP T/C rs17290643. There was no correlation between these alleles and gefitinib response in our population.

\section{EGFR \& HER2 copy number analysis}

Gene copy number was assessed in our patient tumour samples as previous studies have shown a correlation between copy number increases in EGFR $[9,13,15]$ or HER2 [14] and gefitinib response. Two techniques were used to interpret the FISH data for this analysis (Methods).

Increases in EGFR copy number, defined as an EGFR/ CEP7 ratio $\geq 2.0$, were observed in ten of twenty-six tumours (Table 4). Of these ten, three also displayed increased HER2 copy number (HER2/CEP17 ratio $\geq 2.0$ ). HER2 amplification in the absence of EGFR amplification was seen in three additional tumours. Examples of the varying degrees of amplification of these genes are shown in Figure 4. Increased EGFR copy number did not correlate with: the presence of mutation in either EGFR exon 19 (p $=0.130)$ or exon $20(\mathrm{p}=1.00)$; increased HER2 copy number $(\mathrm{p}=0.644)$; gender $(\mathrm{p}=0.457)$; Asian ethnicity $(\mathrm{p}=0.688)$; smoking status $(\mathrm{p}=0.380)$; adenocarcinoma histology ( $\mathrm{p}=0.538)$; or response to gefitinib $(\mathrm{p}=1.00)$. When patients with stable disease are counted among the responders ("disease control"), no correlation with response was observed $(p=0.210)$. Likewise, increased HER2 copy number did not correlate with: the presence of mutation of either EGFR exon $19(\mathrm{p}=1.00)$ or exon $20(\mathrm{p}$ $=1.00)$; increased EGFR copy number $(\mathrm{p}=0.644)$; gender $(\mathrm{p}=0.160)$; Asian ethnicity $(\mathrm{p}=0.645) ;$ smoking status $(\mathrm{p}$ $=0.351)$; adenocarcinoma histology $(\mathrm{p}=1.00)$; or gefit inib response $(\mathrm{p}=1.00)$ and disease control $(\mathrm{p}=0.114)$.

Tumours were also stratified by EGFR and HER2 copy number using the criteria proposed by Cappuzzo et al [13] (Table 4). Seven tumours were identified as FISH+ for EGFR amplification and four tumours were identified as FISH+ for HER2 amplification (high polysomy or gene amplification). Only one of these tumours was FISH+ for both EGFR and HER2 and this was the only sample to meet the EGFR "gene amplification" criteria as proposed by Capuzzo et al $(10 ; \geq 15$ copies in $\geq 10 \%$ of cells). FISH+ status corresponded with an EGFR/CEP7 ratio $\geq 2.0$ in seven of ten samples. FISH+ status corresponded with a HER2/CEP17 ratio $\geq 2.0$ in four of six samples. There was no correlation between EGFR FISH+ status and mutation of either EGFR exon $19(\mathrm{p}=0.0543)$ or exon $20(\mathrm{p}=$ $0.283)$; female gender $(\mathrm{p}=0.378)$; Asian ethnicity $(\mathrm{p}=$ $1.00)$; smoking status ( $\mathrm{p}=1.00)$; adenocarcinoma histology $(\mathrm{p}=0.167)$; response to gefitinib $(\mathrm{p}=0.552)$ or disease control $(\mathrm{p}=0.653)$. Likewise, HER2 FISH+ did not correlate with the presence of mutation of either EGFR exon $19(\mathrm{p}=1.00)$ or exon $20(\mathrm{p}=0.544)$; increased EGFR copy number $(\mathrm{p}=1.00)$; gender $(\mathrm{p}=0.593)$; Asian ethnic- 
Table 2: EGFR exon 19 deletions/substitution

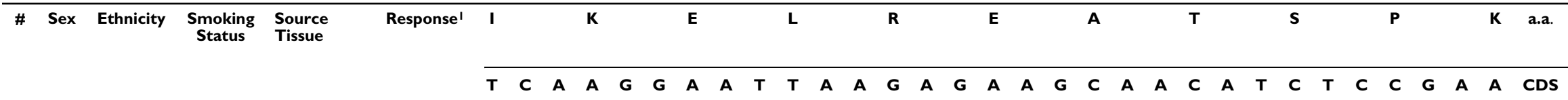

\begin{tabular}{|c|c|c|c|c|c|c|c|c|c|c|c|c|c|c|c|c|c|c|c|c|c|c|c|c|c|c|c|c|c|c|c|c|c|c|c|c|c|}
\hline 11 & $\mathrm{~F}$ & Asian & Unk. & Lung & PR & $T$ & C & A & A & - & - & - & - & - & - & - & - & - & - & - & - & - & - & - & A & $A$ & C & A & $\mathrm{T}$ & C & $T$ & $C$ & $C$ & G & A & A & Het* \\
\hline 22 & M & Asian & $N$ & Lymph Node & PD & $\mathrm{T}$ & C & A & A & G & G & $A$ & A & - & - & - & - & - & C & - & - & - & - & - & - & - & C & A & $\mathrm{T}$ & C & $\mathrm{T}$ & $C$ & C & G & A & A & Het \\
\hline & $\mathrm{F}$ & Asian & $\mathrm{N}$ & Lung & PD & $T$ & C & A & A & $\mathrm{G}$ & $\mathrm{G}$ & A & A & - & - & - & - & - & - & - & - & - & - & - & - & - & - & - & $\mathrm{T}$ & C & $\mathrm{T}$ & C & C & $\mathrm{G}$ & A & A & Del \\
\hline & $\mathrm{F}$ & Asian & $\mathrm{N}$ & Lung & PR & $T$ & C & A & A & - & - & - & - & - & - & - & - & - & - & - & - & - & . & - & A & A & C & A & $\mathrm{T}$ & C & $T$ & C & C & G & A & A & Het* \\
\hline
\end{tabular}

Deletions of L747-A750 were detected in EGFR exon 19. All samples were classified as adenocarcinoma based on histology. Deleted bases are indicated by "-" In the case of patient \#22 thirteen deleted bases were replaced by a single ' $C$ ' thereby retaining the reading frame. In all cases, the ATP-binding residue K745 was retained. In the case of patients \#II and \#66, a synonymous codon change results from the deletion (AAG > AAA) and the K745 ATP-binding residue is unchanged.

$*=$ no mutations detected in normal tissue remaining after microdissection.

$I=$ response as measured radiographically and defined by SWOG modification of the WHO criteria.

$\mathrm{PD}=$ progressive disease, $\mathrm{SD}=$ stable disease, $\mathrm{PR}=$ partial response, Unk. = Unknown 
Table 3: EGFR point mutations

\begin{tabular}{|c|c|c|c|c|c|c|c|c|c|}
\hline \# & Sex & Ethnicity & $\begin{array}{l}\text { Smoking } \\
\text { Status }\end{array}$ & $\begin{array}{l}\text { Source } \\
\text { Tissue }\end{array}$ & Response' & Exon & $\begin{array}{c}\text { CDS } \\
\text { Mutation }\end{array}$ & $\begin{array}{l}\text { Amino } \\
\text { Acid }\end{array}$ & $\begin{array}{c}\text { Previously } \\
\text { Documented }\end{array}$ \\
\hline 44 & $\mathrm{~F}$ & Asian & $\mathrm{N}$ & Pleura & PR & 20 & $\begin{array}{l}\mathrm{G} 2549>\mathrm{TT} \\
\mathrm{C} 2691>\mathrm{CT}\end{array}$ & $\begin{array}{l}\text { S768I } \\
\text { L8I5L }\end{array}$ & $\begin{array}{c}\text { [32-35] } \\
\text { none }\end{array}$ \\
\hline 11 & $\mathrm{~F}$ & Asian & Unk. & Lung & PR & 20 & $\mathrm{G} 2566>$ TT* & V774L & $\operatorname{V774M}[35,36]$ \\
\hline 28 & $M$ & Caucasian & $\mathrm{Y}$ & Brain & SD & 20 & G258I > AG & G779S & G779F [36] \\
\hline 35 & $\mathrm{~F}$ & Caucasian & Unk. & Brain & SD & 20 & $\mathrm{G} 2703>\mathrm{GA}$ & V819V & [37] \\
\hline 47 & $\mathrm{~F}$ & Asian & $\mathrm{N}$ & Lung & SD & 21 & $\mathrm{~T} 2573$ > GG & L858R & {$[5-7,13,15,35,38,39]$} \\
\hline
\end{tabular}

Point mutations detected in EGFR exons 20 and 21 . All samples were classified as adenocarcinoma based on histology. Point mutations altering V774 and G779 have been previously documented to result in amino acid substitutions different than those found in this study.

$*=$ no mutations detected in normal tissue remaining after microdissection

$\mathrm{I}=$ response as measured radiographically and defined by SWOG modification of the WHO criteria [20].

$\mathrm{PD}=$ progressive disease, $\mathrm{SD}=$ stable disease, $\mathrm{PR}=$ partial response, Unk. = Unknown

ity $(\mathrm{p}=0.593)$; smoking status $(\mathrm{p}=1.00)$; adenocarcinoma histology $(\mathrm{p}=0.408)$; response to gefitinib $(\mathrm{p}=$ $0.437)$ or disease control $(\mathrm{p}=0.239)$.

\section{Discussion}

In DNA sequencing studies using patient samples, contaminating normal tissue has the potential to mask tumour-specific features particularly in cases of highly heterogeneous metastatic deposits. To examine somatic features specific to tumours, we employed laser microdissection to isolate cancer cells from surrounding normal tissue. The selectivity of this technique was demonstrated by the identification of EGFR exon 19 deletions in the tumour populations of two patient samples but not the surrounding normal tissue remaining after microdissection.

In the evolving area of biomarkers predictive of response to EGFR tyrosine kinase inhibitors, two hypotheses have arisen, each claiming a specific alteration of EGFR is predictive of response. One hypothesis is that mutations within the EGFR tyrosine kinase domain targeted by these drugs are indicative of a capability to respond [5-7]. The second hypothesis is that the presence of increased gene copy number of EGFR or HER2 is a better predictor of response [13-15]. When investigating the relevance of these features to our own population of lung cancer patients treated with gefitinib, our study detected all of these features occurring both independently and coincidentally in microdissected tumour cells.

Tumours from four of thirty-eight patients contained a form of the exon 19 L747-A750 deletion and one tumour harboured the exon 21 L858R point mutation. Two of the patients with exon 19 deletions were responsive to gefitinib and were also found to have increased EGFR copy number. In the remaining four responders, EGFR muta- tions or gene amplifications that others previously correlated with gefitinib response [5-7] were not observed. These data are consistent with the notion that tumours reliant on amplification of a mutant EGFR allele may be particularly susceptible to inhibition by gefitinib. However, responders without apparent gefitinib-sensitising EGFR alterations may have shown characteristics of response even without treatment or may have responded due to an interaction between gefitinib and a protein other than EGFR [30,31]. To identify alternative genetic features mediating drug response, candidate genes influenced by receptor tyrosine kinase inhibitors need to be identified and studied in patients receiving these drugs.

In this study, we compared two methods of interpreting FISH data and defining increased gene copy number. One technique defined gene amplification as a gene/centromere (e.g. EGFR/CEP7) threshold $\geq 2.0$ while the second technique defined "FISH+" status from the stratification of different gene/centromere ratios into varying degrees of polysomy [13]. While both of these methods identified seven tumours with EGFR amplification, the EGFR/CEP7 ratio $\geq 2$ method identified an additional three tumours which were classified as "Low Polysomy" under the Cappuzzo criteria. While not originally designed for this purpose, we also applied Cappuzzo's criteria [13] to our HER2 FISH data. Again we saw an overlap of the samples identified by both methods as having increased HER2 copy number. However, as with EGFR, the HER2/CEP17 ratio method identified samples not captured by the stratification method but with ratios near the threshold of 2 for amplification. None of these patients responded to gefitinib. These results suggest a need for further refinement of criteria for defining amplification and may reflect the ability of FISH to define precise copy number. Our experience underscores the difficulty in capturing the heterogeneous nature of a tumour population with a single 
Table 4: EGFR and HER2 copy number alterations

\begin{tabular}{|c|c|c|c|c|c|c|c|c|c|c|c|c|}
\hline \# & Sex & Ethnicity & $\begin{array}{c}\text { Smoking } \\
\text { Status }\end{array}$ & Histology & $\begin{array}{l}\text { Source } \\
\text { Tissue }\end{array}$ & Block Type' & Response $^{2}$ & EGFR Mutation & EGFR/CEP7 & HER2/CEPI7 & $\begin{array}{c}\text { EGFR } \\
\text { Stratification }^{3}\end{array}$ & $\begin{array}{c}\text { HER2 } \\
\text { Stratification }^{3}\end{array}$ \\
\hline 9 & $\mathrm{~F}$ & Asian & $\mathrm{N}$ & adeno. & Cerebellum & Tissue Block & SD & Not Sequenced & 2.1 & 1.9 & High Poly. & Low Poly. \\
\hline 11 & $\mathrm{~F}$ & Asian & Unk. & adeno. & Lung & Tissue Block & PR & Exon 19 Del*, Exon 20 V774L & 2.7 & 1.5 & High Poly. & High Trisomy \\
\hline 27 & $\mathrm{~F}$ & Caucasian & Y & SCC & Lung & Tissue Block & PD & None & 2.1 & 1.5 & High Poly. & Low Poly. \\
\hline 34 & $M$ & Caucasian & Y & SCC & Lung & Tissue Block & SD & None & 17.3 & 2.6 & Gene Amp. & High Poly. \\
\hline 36 & M & Asian & Y & adeno. & Pleura & Tissue Block & SD & None & 2.0 & 2.0 & Low Poly. & Low Poly. \\
\hline 40 & M & Caucasian & $Y$ & adeno. & Pleura & Cell Block & SD & None & 3.1 & 1.4 & High Poly. & Low Poly. \\
\hline 42 & $M$ & Caucasian & Y & adeno. & Lymph Node & Tissue Block & Unk. & None & 2.1 & 2.3 & Low Poly. & High Poly. \\
\hline 43 & $\mathrm{~F}$ & Caucasian & Y & adeno. & Lymph Node & Tissue Block & PD & None & 2.7 & 0.9 & High Poly. & Low Trisomy \\
\hline 44 & $\mathrm{~F}$ & Asian & $\mathrm{N}$ & adeno. & Pleura & Tissue Block & PR & Exon 20 S768I, Exon 20 L8I5L & 1.9 & 2.9 & Low Poly. & High Poly. \\
\hline 56 & $M$ & Caucasian & Y & adeno. & Lung & Tissue Block & Unk. & None & 1.5 & 2.0 & High Trisomy & Low Poly. \\
\hline 57 & $M$ & Caucasian & $Y$ & adeno. & Lymph Node & Tissue Block & $S D$ & None & 1.6 & 2.2 & Low Poly. & High Poly. \\
\hline \multirow[t]{3}{*}{64} & $\mathrm{~F}$ & Caucasian & $Y$ & & & & & & & & & \\
\hline & & & Pre Rx: & adeno. & Lymph Node & Tissue Block & - & None & 1.0 & 1.2 & Low Trisomy & High Trisomy \\
\hline & & & Post Rx: & adeno. & Pericaridium & Tissue Block & $S D$ & None & 2.2 & 1.3 & Low Poly. & Low Trisomy \\
\hline 66 & $\mathrm{~F}$ & Asian & $\mathrm{N}$ & adeno. & Lung & Tissue Block & PR & Exon $19 \mathrm{Del}^{*}$ & 2.9 & 1.2 & High Poly. & Low Trisomy \\
\hline
\end{tabular}

Patient data provided for samples displaying increased EGFR or HER2 copy number (Probe/CEP ratio > 2.0) or identified as FISH+ (High Polysomy or Gene Amplification)

$*=$ no mutations detected in normal tissue remaining after microdissection

I = source of patient material (Tissue Block = microdissected formalin-fixed paraffin-embedded tissue block; Cell Block = whole section or microdissected formalin-fixed paraffin-embedded cell block; Cytology = scraped cytology slide)

2 = response as measured radiographically and defined by SWOG modification of the WHO criteria [20].

$\mathrm{PD}=$ progressive disease, $\mathrm{SD}=$ stable disease, $\mathrm{PR}=$ partial response, Unk. = Unknown

$3=$ Copy number stratification as proposed by Cappuzzo et al [13]. (Disomy $=<2$ copies in $>90 \%$ of cells, Low Trisomy $=\leq 2$ copies in $\geq 40 \%$ of cells, 3 copies in $10-40 \%$ of cells, $\geq 4$ copies in $<10 \%$ of cells, High Trisomy $=\leq 2$ copies in $\geq 40 \%$ of cells, 3 copes in $\geq 40 \%$ of cells, $\geq 4$ copes in $<10 \%$ of cells, Low Polysomy: $\geq 4$ copies in $10-40 \%$ of cells, High Polysomy $=\geq 4$ copies in $40 \%$ of cells, Gene Amplification $=\geq 15$ copies in $\geq 10 \%$ of cells) 


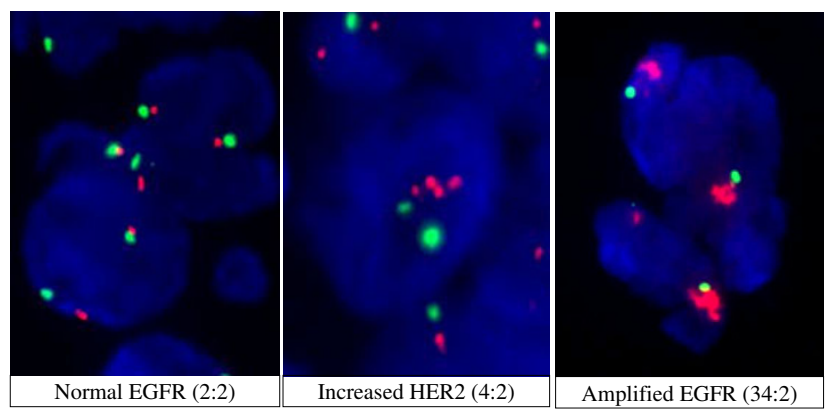

Figure 4

Examples of tumours with increased gene copy number detected by FISH. Gene copy number visualized by fluorescent in situ hybridization (FISH). Blue DAPI stain identifies the DNA present in each cell's nucleus. Red Cy5labelled probes hybridize to the gene region targeted by each assay (EGFR or HER2). Green Cy3-labelled probes target the centromere of the chromosome appropriate for the genespecific assay (chromosome 7 for EGFR, chromosome 17 for HER2). The ratio reported is the number of red probes/ green probes (genes/chromosome) based on an average of 40 cells. A) Tumour cell without increased EGFR copy number, B) Tumour cell with increased HER2 copy number C) Tumour cell with greatly amplified EGFR.

measurement. An understanding of the biological implications of EGFR gene amplification is needed to refine the predictive specificity of these tests.

\section{Conclusion}

Recently, several studies have correlated gefitinib response with either EGFR mutation [5-9] or increased EGFR copy number [9,13-15] but the true predictive value of these features is still under debate $[18,19]$. While we observed EGFR DNA sequence mutations and increases in EGFR and HER2 gene copy number in several of our specimens, we were unable to statistically correlate the presence of any of these molecular features with response. While these findings may be due to a lack of statistical power due to our small sample size, our study differs from others in our use of a population with a large Asian component in a North American setting. Even though EGFR status was not a single predictive factor of drug response in our small sample set, its assessment can increase the specificity of selecting patients likely to respond to these drugs. To improve the sensitivity of screening for potential responders, additional features other than EGFR that mediate drug response need to be identified. Clinical criteria including gender, histology, smoking status and ethnicity, are likely to continue to play a role in the selection of patients for treatment with the EGFR tyrosine kinase inhibitors in NSCLC as indirect surrogates for molecular features, until completion of prospective clinical trials validating direct predictive tests of tumour biology. Such trials should be designed specifically to examine the utility of multiple molecular predictors of response concurrently.

\section{Competing interests}

The author(s) declare that they have no competing interests.

\section{Authors' contributions}

TJP participated in the study coordination, performed the DNA extraction, qualification, and sequence analysis, and generated drafts of the manuscript. GB conceived of the study and participated in its design as well as treated patients and identified patients for study. LB, MS, JF reviewed patient samples and performed microdissection. CS and DH carried out the FISH studies. RO served as the reference pathologist and reviewed all patient samples. $\mathrm{CH}, \mathrm{NM}, \mathrm{BM}$ treated patients and identified patients for this study. JE coordinated sample acquisition. JV oversaw the microdissection process. JL and MAM conceived of the study, participated in its design and coordination, and contributed to writing the manuscript. All authors have read and approved the final manuscript.

\section{Additional material}

\section{Additional file 1}

Supplemental Table 1 - Summary of all patient clinical data and molecular status. A table containing clinical data and molecular status of all patients studied.

Click here for file

[http://www.biomedcentral.com/content/supplementary/14712407-7-128-S1.doc]

\section{Acknowledgements}

The authors wish to thank the BC Cancer Agency Michael Smith Genome Sciences Centre Cancer Genetics Group lead by Angela Brooks-Wilson for technical assistance and insightful discussion. We are grateful to Pat Allard (BCCA) for sectioning samples and to Holly Eely (BCCA) for facilitating sample acquisition. MAM is a Scholar of the Michael Smith Foundation for Health Research and a Terry Fox Young Investigator. TJP was supported by an Eli Lily Lung Cancer Research Fellowship. A portion of this work was supported by a Genome Canada/Genome BC Cancer Genomics grant. Assistance with statistical analysis was provided by Aline Tabet of the University of British Columbia Department of Statistics Short Term Consulting Service.

\section{References}

I. Canadian Cancer Statistics 2006. Toronto, Canada , Canadian Cancer Society/National Cancer Institute of Canada; 2006.

2. Laskin JJ, Sandler AB: Epidermal growth factor receptor: a promising target in solid tumours. Cancer Treat Rev 2004, 30:1-17.

3. Fukuoka M, Yano S, Giaccone G, Tamura T, Nakagawa K, Douillard JY, Nishiwaki Y, Vansteenkiste J, Kudoh S, Rischin D, Eek R, Horai T, Noda K, Takata I, Smit E, Averbuch S, Macleod A, Feyereislova A, Dong RP, Baselga J: Multi-institutional randomized phase II trial of gefitinib for previously treated patients with advanced 
non-small-cell lung cancer (The IDEAL I Trial). J Clin Oncol 2003, 2 I (I 2):2237-2246.

4. Kris MG, Natale RB, Herbst RS, Lynch TJ, Prager D, Belani CP, Schiller $\mathrm{JH}$, Kelly K, Spiridonidis H, Sandler A, Albain KS, Cella D, Wolf MK, Averbuch SD, Ochs JJ, Kay AC: Efficacy of gefitinib, an inhibitor of the epidermal growth factor receptor tyrosine kinase, in symptomatic patients with non-small cell lung cancer: a randomized trial. JAMA 2003, 290(16):2149-2158.

5. Paez JG, Janne PA, Lee JC, Tracy S, Greulich H, Gabriel S, Herman P, Kaye FJ, Lindeman N, Boggon TJ, Naoki K, Sasaki H, Fujii Y, Eck MJ, Sellers WR, Johnson BE, Meyerson M: EGFR mutations in lung cancer: correlation with clinical response to gefitinib therapy. Science 2004, 304: 1497-1500.

6. Lynch TJ, Bell DW, Sordella R, Gurubhagavatula S, Okimoto RA, Brannigan BW, Harris PL, Haserlat SM, Supko JG, Haluska FG, Louis DN, Christiani DC, Settleman J, Haber DA: Activating mutations in the epidermal growth factor receptor underlying responsiveness of non-small-cell lung cancer to gefitinib. N EnglJ Med 2004, 350:2129-2139.

7. Pao W, Miller V, Zakowski M, Doherty J, Politi K, Sarkaria I, Singh B, Heelan R, Rusch V, Fulton L, Mardis E, Kupfer D, Wilson R, Kris M, Varmus H: EGF receptor gene mutations are common in lung cancers from "never smokers" and are associated with sensitivity of tumors to gefitinib and erlotinib. Proc Natl Acad Sci USA 2004, I 01 (36): |3306-1331I.

8. Taron M, Ichinose Y, Rosell R, Mok T, Massuti B, Zamora L, Mate JL, Manegold C, Ono M, Queralt C, Jahan T, Sanchez JJ, Sanchez-Ronco M, Hsue V, Jablons D, Sanchez JM, Moran T: Activating mutations in the tyrosine kinase domain of the epidermal growth factor receptor are associated with improved survival in gefitinibtreated chemorefractory lung adenocarcinomas. Clin Cancer Res 2005, I I( I6):5878-5885.

9. Takano T, Ohe Y, Sakamoto H, Tsuta K, Matsuno Y, Tateishi U, Yamamoto S, Nokihara H, Yamamoto N, Sekine I, Kunitoh H, Shibata T, Sakiyama T, Yoshida T, Tamura T: Epidermal growth factor receptor gene mutations and increased copy numbers predict gefitinib sensitivity in patients with recurrent non-smallcell lung cancer. J Clin Oncol 2005, 23(28):6829-6837.

10. Ho C, Murray N, Laskin J, Melosky B, Anderson H, Bebb G: Asian ethnicity and adenocarcinoma histology continues to predict response to gefitinib in patients treated for advanced nonsmall cell carcinoma of the lung in North America. Lung Cancer 2005, 49(2):225-23I.

II. Giaccone G, Rodriguez JA: EGFR inhibitors: what have we learned from the treatment of lung cancer? Nat Clin Pract Oncol 2005, 2(I I):554-56I.

12. Inoue A, Suzuki T, Fukuhara T, Maemondo M, Kimura Y, Morikawa N, Watanabe H, Saijo Y, Nukiwa T: Prospective phase II study of gefitinib for chemotherapy-naive patients with advanced non-small-cell lung cancer with epidermal growth factor receptor gene mutations. J Clin Oncol 2006, 24(2I):3340-3346.

13. Cappuzzo F, Hirsch FR, Rossi E, Bartolini S, Ceresoli GL, Bemis L, Haney J, Witta S, Danenberg K, Domenichini I, Ludovini V, Magrini E, Gregorc V, Doglioni C, Sidoni A, Tonato M, Franklin WA, Crino L, Bunn PAJ, Varella-Garcia M: Epidermal growth factor receptor gene and protein and gefitinib sensitivity in non-small-cell lung cancer. J Nat/ Cancer Inst 2005, 97(9):643-655.

14. Cappuzzo F, Varella-Garcia M, Shigematsu H, Domenichini I, Bartolini S, Ceresoli GL, Rossi E, Ludovini V, Gregorc V, Toschi L, Franklin WA, Crino L, Gazdar AF, Bunn PA, Hirsch FR: Increased HER2 gene copy number is associated with response to gefitinib therapy in epidermal growth factor receptor-positive nonsmall-cell lung cancer patients. J Clin Oncol 2005, 23(22):5007-50।8.

15. Tsao MS, Sakurada A, Cutz JC, Zhu CQ, Kamel-Reid S, Squire J, Lorimer I, Zhang T, Liu N, Daneshmand M, Marrano P, da C Santos, G., Lagarde A, Richardson F, Seymour L, Whitehead M, Ding K, Pater J, Shepherd FA: Erlotinib in lung cancer - molecular and clinical predictors of outcome. N Engl J Med 2005, 353(2): I33-I44.

16. Brabender J, Danenberg KD, Metzger R, Schneider PM, Park J, Salonga $\mathrm{D}$, Holscher AH, Danenberg PV: Epidermal growth factor receptor and HER2-neu mRNA expression in non-small cell lung cancer Is correlated with survival. Clin Cancer Res 200I, 7(7): $1850-1855$.

17. Onn A, Correa AM, Gilcrease M, Isobe T, Massarelli E, Bucana CD, O'Reilly MS, Hong WK, Fidler IJ, Putnam JB, Herbst RS: Synchro- nous overexpression of epidermal growth factor receptor and HER2-neu protein is a predictor of poor outcome in patients with stage I non-small cell lung cancer. Clin Cancer Res 2004, I0(I Pt I):|36-|43.

18. Johnson BE, Janne PA: Selecting patients for epidermal growth factor receptor inhibitor treatment: A FISH story or a tale of mutations? J Clin Oncol 2005, 23(28):68I3-68I6.

19. Shepherd FA, Tsao MS: Unraveling the mystery of prognostic and predictive factors in epidermal growth factor receptor therapy. J Clin Oncol 2006, 24(7): 1219-20; author reply I220-1.

20. Green S, Weiss GR: Southwest Oncology Group standard response criteria, endpoint definitions and toxicity criteria. Invest New Drugs 1992, I 0(4):239-253.

21. Kent WJ, Sugnet CW, Furey TS, Roskin KM, Pringle TH, Zahler AM, Haussler D: The Human Genome Browser at UCSC. Genome Res 2002, I 2(6):996-1006.

22. UCSC Genome Browser website [http://genome.ucsc.edu/]

23. Rozen S, Skaletsky H: Primer3 on the WWW for general users and for biologist programmers. In Bioinformatics Methods and Protocols: Methods in Molecular Biology Edited by: Krawetz S MS. Totowa, NJ , Humana Press; 2000:365-386.

24. Ewing B, Green P: Base-calling of automated sequencer traces using phred. II. Error probabilities. Genome Res 1998, 8(3): $186-194$

25. Gordon D, Abajian C, Green P: Consed: a graphical tool for sequence finishing. Genome Res 1998, 8(3): 195-202.

26. Sherry ST, Ward MH, Kholodov M, Baker J, Phan L, Smigielski EM, Sirotkin K: dbSNP: the NCBI database of genetic variation. Nucleic Acids Res 200I, 29(I):308-3II

27. dbSNP Home Page [http://www.ncbi.nlm.nih.gov/projects/SNP/]

28. Pao W, Miller VA, Politi KA, Riely G], Somwar R, Zakowski MF, Kris MG, Varmus H: Acquired Resistance of Lung Adenocarcinomas to Gefitinib or Erlotinib Is Associated with a Second Mutation in the EGFR Kinase Domain. PLoS Med 2005, 2:e73.

29. Marchetti A, Felicioni L, Buttitta F: Assessing EGFR mutations. $N$ Engl J Med 2006, 354(5):526-8; author reply 526-8.

30. Brehmer D, Greff Z, Godl K, Blencke S, Kurtenbach A, Weber M, Muller S, Klebl B, Cotten M, Keri G, Wissing J, Daub H: Cellular targets of gefitinib. Cancer Res 2005, 65(2):379-382.

31. Fabian MA, Biggs WH, Treiber DK, Atteridge CE, Azimioara MD, Benedetti MG, Carter TA, Ciceri P, Edeen PT, Floyd M, Ford JM, Galvin M, Gerlach JL, Grotzfeld RM, Herrgard S, Insko DE, Insko MA, Lai AG, Lelias JM, Mehta SA, Milanov ZV, Velasco AM, Wodicka LM, Patel HK, Zarrinkar PP, Lockhart DJ: A small molecule-kinase interaction map for clinical kinase inhibitors. Nat Biotechnol 2005, 23(3):329-336.

32. Eberhard DA, Johnson BE, Amler LC, Goddard AD, Heldens SL, Herbst RS, Ince WL, Jänne PA, Januario T, Johnson DH, Klein P, Miller VA, Ostland MA, Ramies DA, Sebisanovic D, Stinson JA, Zhang YR, Seshagiri S, Hillan KJ: Mutations in the epidermal growth factor receptor and in KRAS are predictive and prognostic indicators in patients with non-small-cell lung cancer treated with chemotherapy alone and in combination with erlotinib. J Clin Oncol 2005, 23(25):5900-5909.

33. Huang SF, Liu HP, Li LH, Ku YC, Fu YN, Tsai HY, Chen YT, Lin YF, Chang WC, Kuo HP, Wu YC, Chen YR, Tsai SF: High frequency of epidermal growth factor receptor mutations with complex patterns in non-small cell lung cancers related to gefitinib responsiveness in Taiwan. Clin Cancer Res 2004, 10(24):8195-8203.

34. Kosaka T, Yatabe Y, Endoh H, Kuwano H, Takahashi T, Mitsudomi T: Mutations of the epidermal growth factor receptor gene in lung cancer: biological and clinical implications. Cancer Res 2004, 64(24):8919-8923.

35. Shigematsu H, Lin L, Takahashi T, Nomura M, Suzuki M, Wistuba II, Fong KM, Lee H, Toyooka S, Shimizu N, Fujisawa T, Feng Z, Roth JA, Herz J. Minna JD, Gazdar AF: Clinical and biological features associated with epidermal growth factor receptor gene mutations in lung cancers. J Natl Cancer Inst 2005, 97(5):339-346.

36. Yang SH, Mechanic LE, Yang P, Landi MT, Bowman ED, Wampfler J, Meerzaman D, Hong KM, Mann F, Dracheva T, Fukuoka J, Travis W, Caporaso N, Harris CC, Jen J: Mutations in the Tyrosine Kinase Domain of the Epidermal Growth Factor Receptor in NonSmall Cell Lung Cancer. Clinical Cancer Res 2005, I I:2 I 06-2 I I0. 
37. Su MC, Lien HC, Jeng YM: Absence of epidermal growth factor receptor exon 18-2I mutation in hepatocellular carcinoma. Cancer Lett 2005, 224(I): I 17-121.

38. Bell DW, Lynch TJ, Haserlat SM, Harris PL, Okimoto RA, Brannigan BW, Sgroi DC, Muir B, Riemenschneider MJ, lacona RB, Krebs AD, Johnson DH, Giaccone G, Herbst RS, Manegold C, Fukuoka M, Kris MG, Baselga J, Ochs JS, Haber DA: Epidermal growth factor receptor mutations and gene amplification in non-small-cell lung cancer: molecular analysis of the IDEAL/INTACT gefitinib trials. J Clin Oncol 2005, 23(3I):808I-8092.

39. Marchetti A, Martella C, Felicioni L, Barassi F, Salvatore S, Chella A, Camplese PP, larussi T, Mucilli F, Mezzetti A, Cuccurullo F, Sacco R, Buttitta F: EGFR mutations in non-small-cell lung cancer: analysis of a large series of cases and development of a rapid and sensitive method for diagnostic screening with potential implications on pharmacologic treatment. J Clin Oncol 2005, 23:857-865.

\section{Pre-publication history}

The pre-publication history for this paper can be accessed here:

http://www.biomedcentral.com/1471-2407/7/128/pre pub

Publish with Bio Med Central and every scientist can read your work free of charge

"BioMed Central will be the most significant development for disseminating the results of biomedical research in our lifetime. "

Sir Paul Nurse, Cancer Research UK

Your research papers will be:

- available free of charge to the entire biomedical community

- peer reviewed and published immediately upon acceptance

- cited in PubMed and archived on PubMed Central

- yours - you keep the copyright

Submit your manuscript here:

http://www.biomedcentral.com/info/publishing_adv.asp
BiolMedcentral 